\title{
Peer Support Program for Cancer Clients - South Indian Experience
}

\author{
${ }^{1}$ Yayathee Subbarayalu, ${ }^{2}$ Susila Chandrasekaran, ${ }^{3}$ Kanchana Khan, ${ }^{4}$ Santhanam T \\ ${ }^{I}$ Research Fellow - ICMR, International Centre for Collaborative Research, Omayal \\ Achi College of Nursing, Chennai \\ ${ }^{2}$ Principal, Billroth College of Nursing, Chennai \\ ${ }^{3}$ Principal, Omayal Achi College of Nursing, Chennai \\ ${ }^{4}$ Director, SDS Institute of Behavioral Sciences, Chennai \\ Email: susilachandrasekaran@yahoo.com
}

\begin{abstract}
Background/Purpose: Peer support program for cancer clients was well known and accepted one all over the world. In India peer support for cancer is informal and not as a support model in care. Clients show good coping with peer support. A journey started with an aim of bringing in standard training program for peer support in India and to make them as part of healing team.

Methods: A Training module was prepared with expert validation. The criteria's for becoming volunteer were completed treatment successfully, healthy on regular follow up, completed at least primary education and willing to spend one hour in a day. A 2 half day workshop with pre test of self rated skill checklist followed by post test evaluation of self after one month and client rating of satisfaction with peer was planned. Incentives were provided for undergoing the training and also for providing peer support. Informed consent was obtained.

Results: Peer identification process was a huge challenge as people are stigmatized over the diagnosis and not willing to volunteer even with incentives. In about 3 months, 40 eligible clients were asked and only 5 clients with breast cancer consented for training. Training was given and they faced difficulty with providing face to face support which was changed into telephonic support. Clients and peers expressed satisfaction over the process. The Initial hiccup was overcome and now many volunteers willing to undergo training.

Conclusion: A formal training program for peer support has been initiated in India and effectiveness is being tested with a randomized trial and results so far are promising for the care of clients with cancer.
\end{abstract}

Key words: Peer Support, Cancer support, Peer training, Peer support for cancer, Breast cancer support, Peer volunteer.

\section{Introduction}

Cancer diagnosis and treatment creates a lot of psychological and social agony in the clients and they are left blank many times during the treatment journey and look up for someone who could support. Psychological support plays a major role in cancer treatment and successful recovery. Health care professionals provide a very good support for the cancer clients; instead there is always a gap in improving the quality of life of those clients. Health care professionals use peers as a support model for many diseases all around the world. Peer support is recognized as an important source of support in providing care for chronic health problems such as addiction, Diabetes, Cancer etc.

Peer support refers to support offered to people with a particular illness by people who have also experienced the same illness. Sharing experiences is the essence of peer support and enables a peer to offer experiential empathy, something generally beyond the scope of health professionals. The emotional, informational and appraisal support as core attributes of peer support, with the mutual identification, shared experiences and sense of belonging developed through peer support thought to impact psychological outcomes positively. Peer support 
programs are based on the premise that support from others who have been through a similar experience can help reduce the negative impacts of this disease.

Louisa M. Hoey et al did a systematic review of peer support programs for people with cancer using electronic search in CINAHL (Cumulative Index to Nursing and Allied Health Literature), MEDLINE and PsychINFO databases published from 1980 to April 2007. Data on characteristics of the peer-support program, sample size, design, measures, and findings were extracted and papers were also rated with respect to research quality (categories 'poor', 'fair' or 'good'). The results of the search showed that Forty-three research papers that included data from at least 1 group comparative papers, and 10 papers reporting eight randomized controlled trials (RCTs). Five models of peer support were identified such as oneon-one face-to-face, one-on-one telephone, group face-to-face, group telephone, and group Internet. They concluded stating that papers indicated a high level of satisfaction with peersupport programs; however, evidence for psychosocial benefit was mixed. They said that one to one face to face peer support program will be more effective and should be given priority.

Many Studies have showed positive benefits of peer support on not just cancer but also in various other illness and special mention towards recovery from addiction. In India peer support for cancer is informal and not as a support model in care. Clients show good coping with peer support. A journey started with an aim of bringing in standard training program for peer support in India and to make them as part of healing team.

\section{Aim}

To train the peers to provide psychological support to cancer clients.

\section{Objectives}

1. To test the self rated skills in becoming peer volunteer for cancer support before and after training.

2. To test the satisfaction of cancer clients towards their peer's support.

\section{Methods}

Peer Volunteer support model for cancer clients was planned in a step wise manner. The various steps and activities undertaken are as follows,

\section{Step 1: Preparation of training module}

A training module was prepared to create peer volunteer support for cancer client. The training module was prepared after extensive literature review and expert validation. The module consisted of 5 sections as given in table 1 .

Table 1: List of contents in Peer Support Training Module for Cancer Clients

\begin{tabular}{|l|l|}
\hline Module Section & Content \\
\hline 1. & Peer volunteer support, goals \& standards \\
\hline 2. & Self care \\
\hline 3. & Specific cancer type review (e.g. Breast/ Cervix) \\
\hline 4. & Communication \& counseling skills \\
\hline 5. & Peer support process \\
\hline
\end{tabular}

The training module consisted of section I on peer volunteer support goals and standards which give a brief introduction about the need for peer support, do's and don'ts of peer support and principles of peer support. Section II dealt with self care activities as self health is most important for a cancer conqueror before providing support to his/her peer. Section III was a customized package where the review of specific cancer type was dealt based on the peer's type of cancer. Section IV dealt about the various communication and counseling skills which are required for providing counseling/peer support for the cancer clients. Section V dealt about the actual peer support process which was about how to do the peer support in 
practical scenario, steps in doing the peer support, here specific guidelines for face to face and telephonic support provided to the volunteers.

\section{Step 2: Identification of peer volunteers}

Peer volunteers were identified based on the criteria determined by the experts.

\section{Criteria for selection of peer volunteers}

1. Must have completed cancer treatment successfully.

2. Willing to spend at least one hour every day.

3. Agree to a background check, health screening provided at no cost to volunteer

4. Exhibit a patient, resourceful and friendly demeanor

5. Capable of working with a diverse group of people

6. Have completed at least primary education.

7. Understand and able to communicate orally in Tamil or Telugu.

\section{Step 3: Training of peer volunteers}

Peer volunteers were identified based on the criteria and the training was provided in a 2 half day session with one week interval between each session for reflection. The training program was planned as a group session starting with self introduction followed by pre test of self rated skills on becoming a peer volunteer and first three modules were delivered on the first half day which had four hours with a break of Half hour in between. The first day session was followed by one week reflection and peers were asked to follow the self care activities as taught. $2^{\text {nd }}$ half day training began with reflection of peer volunteer and the remaining modules were delivered in 4 hour session with a half hour break in between. The mode of delivery of the contents were in a form of discussion, debriefing session of peer volunteer's experience, role play of counseling sessions and practice of skills needed for peer counseling.

\section{Step 4: Evaluation of peer volunteers}

After one month of training peer volunteers were assessed for the self rating skills and clarifications given on areas where they lack skill. Clients were then given to the peer volunteers to provide their psychological support through face to face sessions and telephonic follow ups. After one month of peer support clients provided their feedback over the peer counseling. Constant motivation and support provided to the peer volunteers during the support session.

\section{Results and discussion}

\section{Selection of Peer Volunteers}

Peer identification process was a huge challenge as people are stigmatized over the diagnosis and not willing to volunteer even with incentives. In about 3 months, 40 eligible clients were asked and only 5 clients with breast cancer consented for training. The idea of peer support was very informal and the support system was once in a while and not as regular part of the medical team.

\section{Training of Peer Volunteers}

Peer Volunteers were called for training in a group, but group training was not able to be done with constraints like peer volunteers not able to come on a particular day (day feasible for one person was not feasible for another) and lack of supportive personnel to accompany them to the training centre. Hence, individualized training was given for the peer volunteers at their convenient places such as in their Home and Hospital. Individualized training was also found to be more supportive as they opened up much better and their queries were addressed more clearly.

\section{Self rating of skills}

Pre and post skill rating on becoming a peer volunteer was taken from the clients and all 5 clients trained so far expressed high level of confidence in performing the role of peer 
South American Journal of Nursing

Special Edition 2016

volunteer. The pre and post skill was assessed using a rating scale and the results are given in table 2 .

Table 2: Findings of Pre and Post Self skill rating of peer volunteers

\begin{tabular}{|c|c|c|c|c|c|c|c|c|c|c|}
\hline \multirow[t]{2}{*}{ Questions } & \multicolumn{2}{|c|}{$\begin{array}{l}\text { Excellent } \\
\text { or a great } \\
\text { deal } 1\end{array}$} & \multicolumn{2}{|c|}{$\begin{array}{l}\text { Above } \\
\text { Average } \\
\text { or much } \\
2\end{array}$} & \multicolumn{2}{|c|}{$\begin{array}{l}\text { Average } \\
\text { or } \\
\text { somewha } \\
\text { t } 3\end{array}$} & \multicolumn{2}{|c|}{$\begin{array}{l}\text { Below } \\
\text { Average } \\
\text { or } \\
\text { Seldom } 4\end{array}$} & \multicolumn{2}{|c|}{$\begin{array}{l}\text { Extreme } \\
\text { ly Poor } \\
\text { or } \\
\text { None } \\
5\end{array}$} \\
\hline & $\begin{array}{l}\text { Pre } \\
\text { test }\end{array}$ & \begin{tabular}{|l|} 
Pos \\
t \\
test
\end{tabular} & $\begin{array}{l}\text { Pre } \\
\text { test }\end{array}$ & \begin{tabular}{|l|} 
Pos \\
t \\
test
\end{tabular} & $\begin{array}{l}\text { Pre } \\
\text { test }\end{array}$ & $\begin{array}{l}\text { Pos } \\
\text { t } \\
\text { test }\end{array}$ & $\begin{array}{l}\text { Pre } \\
\text { test }\end{array}$ & $\begin{array}{l}\text { Pos } \\
\text { t } \\
\text { test }\end{array}$ & $\begin{array}{l}\text { Pr } \\
\text { e } \\
\text { tes } \\
\text { t }\end{array}$ & $\begin{array}{l}\text { Pos } \\
\text { t } \\
\text { test }\end{array}$ \\
\hline $\begin{array}{l}\text { 1. How would you rate } \\
\text { previous knowledge } \\
\text { peer counseling }\end{array}$ & $\begin{array}{l}\text { your } \\
\text { of peer }\end{array}$ & $\begin{array}{l}5 \\
\text { to }\end{array}$ & & & 1 & & 4 & & & \\
\hline $\begin{array}{l}\text { 2. How would you rate } \\
\text { confidence level as a } \\
\text { volunteer? }\end{array}$ & $\begin{array}{l}\text { ylour ch } \\
\text { peer }\end{array}$ & ufrent & 4 & & & & & & & \\
\hline $\begin{array}{l}\text { 3. How would you rate } \\
\text { understanding for th } \\
\text { peer counseling? }\end{array}$ & $\begin{array}{l}\text { your ch } \\
\text { e ration }\end{array}$ & $\begin{array}{l}\text { ufrent } \\
\text { ale for }\end{array}$ & & 1 & 2 & & 3 & & & \\
\hline $\begin{array}{l}\text { 4. How would you rate } \\
\text { knowledge of your } \\
\text { peer counselor? }\end{array}$ & $\begin{array}{l}\text { your } \\
\text { poundar }\end{array}$ & \begin{tabular}{|c|c}
$\mathbf{3}$ & \\
ies as & a
\end{tabular} & & 2 & & & & & 5 & \\
\hline $\begin{array}{l}\text { 5. How would you rate } \\
\text { confidence in suppor } \\
\text { someone with breast }\end{array}$ & $\begin{array}{l}\text { your ch } \\
\text { rting } \\
\text { cancer }\end{array}$ & ufrent & & 1 & 2 & & 3 & & & \\
\hline $\begin{array}{l}\text { 6. How would your knc } \\
\text { about self care strate }\end{array}$ & $\begin{array}{l}\text { owledge } \\
\text { gies? }\end{array}$ & & & 2 & 3 & & 2 & & & \\
\hline $\begin{array}{l}\text { 7. How would you } \\
\text { rate your current } \\
\text { understanding of } \\
\text { effective } \\
\text { communication and } \\
\text { counseling skills? }\end{array}$ & & 4 & & 1 & 2 & & & & 3 & \\
\hline $\begin{array}{l}\text { 8. How would you } \\
\text { rate your current } \\
\text { knowledge about } \\
\text { breast cancer and } \\
\text { its treatment? }\end{array}$ & & 5 & & & 3 & & 2 & & & \\
\hline $\begin{array}{l}\text { 9. How confident are } \\
\text { you in conducting a } \\
\text { face to face and } \\
\text { telephonic } \\
\text { counseling with } \\
\text { your peer? }\end{array}$ & & 4 & & 1 & 4 & & 1 & & & \\
\hline $\begin{array}{l}\text { 10. How would you rate } \\
\text { comfort level to rec } \\
\text { individual that need } \\
\text { from a professional? }\end{array}$ & $\begin{array}{l}\text { your cl } \\
\text { gnize a } \\
\text { additio }\end{array}$ & $\begin{array}{l}\text { ufrent } \\
\text { an } \\
\text { onal hel }\end{array}$ & & & 3 & & & & 2 & \\
\hline
\end{tabular}




\section{Peer Counseling Session}

Peer support was initially planned as face to face sessions with telephonic sessions and peer volunteers were not able to come in person to the hospital most of the time and hence a complete telephonic support model was finalized and each peer volunteer was given clients periodically and they have provided good psychological support and the clients have expressed high level of satisfaction with the peer support.

\section{Lessons Learnt}

1. Peer support was highly useful in reducing the psychological problems of the clients.

2. Telephonic support model was found to be effective and many Peer volunteers are willing to provide telephonic based support.

3. Individualized training will be more effective than group training.

\section{Conclusion}

A formal training program for peer support has been initiated in India and effectiveness is being tested with a randomized trial and results so far are promising for the care of clients with cancer. Peer volunteer training and support will be brought under the formal stream of care for cancer clients soon.

Acknowledgement: Indian Council of Medical Research Fellowship Grant to carry out the project work.

\section{References}

[1.] Abraham, A. (n.d.). Cancer support. Nursing Standard: Official Newspaper of the Royal College of Nursing, 22(34), 59.

[2.] Bisson, J. I. (2009). Systematic Review of Psychological First Aid. Mhpss.Net. Retrieved from http://mhpss.net/wp-content/uploads/group-documents/148/1321872322-

PFASystematicReviewBissonCatrin.pdf

[3.] Brymer, M., Jacobs, a, Layne, C., Pynoos, R., Ruzek, J., Steinberg, a, ... Watson, P. (2006). National Child Traumatic Stress Network and National Center for PTSD. Psychological First Aid: Field Operations Guide. 2nd Edition.

[4.] Campbell, H. S., Phaneuf, M. R., \& Deane, K. (2004). Cancer peer support programs-do they work? Patient Education and Counseling, 55(1), 3-15. http://doi.org/10.1016/j.pec.2003.10.001

[5.] Giese-Davis, J., Bliss-Isberg, C., Carson, K., Star, P., Donaghy, J., Cordova, M. J., ... Spiegel, D. (2006). The effect of peer counseling on quality of life following diagnosis of breast cancer: An observational study. Psycho-Oncology, 15(11), 1014-1022. http://doi.org/10.1002/pon.1037

[6.] Griesser, V. (2010). Prostate cancer Peer support groups: the Geneva experience, (September).

[7.] Georgia Peer Support Project. "Code of Ethics for Certified Peer Supporters. http://www.disabilitylink.org/docs/psp/Code\%20of\%20Ethics.html. Accessed 15 February 2008.

[8.] Hoey, L. M., Ieropoli, S. C., White, V. M., \& Jefford, M. (2008). Systematic review of peer-support programs for people with cancer. Patient Education and Counseling, 70(3), 315-337. http://doi.org/10.1016/j.pec.2007.11.016

[9.] Høybye, M. T., Dalton, S. O., Deltour, I., Bidstrup, P. E., Frederiksen, K., \& Johansen, C. (2010). Effect of Internet peer-support groups on psychosocial adjustment to cancer: a randomised study. British Journal of Cancer, 102(9), 1348-1354. http://doi.org/10.1038/sj.bjc.6605646

[10.] Mitchell, A. J., Ferguson, D. W., Gill, J., Paul, J., \& Symonds, P. (2013). Depression and anxiety in long-term cancer survivors compared with spouses and healthy controls: A systematic review and meta-analysis. The Lancet Oncology, 14(8), 721-732. http://doi.org/10.1016/S1470-2045(13)70244-4

[11.] Parlewar, R., Rathore, M., Dadwal, D., Prasad, H., \& Medical, G. (2012). Global Journal of Medicine. Global Journal of Medicine and Public Health, 1(June), 24-28.

[12.] Peer Support. (2009). Science. http://doi.org/10.1126/science.323.5910.121

[13.] Prefecture, D., \& Nan, Y. (2007). HIV and AIDS Peer Education and Life Skills Training Workshop ( A Training Guide ) June 2007, (June), 0-58. 
South American Journal of Nursing

Special Edition 2016

[14.] Provincial Hospice Palliative Care Volunteer Resource Manual Provincial Hospice Palliative Care Volunteer Resource Manual. (n.d.). Cancer.

[15.] Report, M. T. (2006). Better Skills Better Jobs Better Health. Framework, (March).

[16.] Resources, P. S. (2013). AgrAbility, 1-22.

[17.] Volunteer Training in British Columbia A Guide To Hospice Volunteer Training in British Columbia British Columbia Hospice Palliative Care Association. (n.d.).

[18.] Who. (1944). Psychological First Aid - Guide for field workers. Who, 44(8), 813. http://doi.org/10.2307/3416674 